\title{
Electrical Parameters Determination from Base Thickness Optimization in a Silicon Solar Cell under Influence of the Irradiation Energy Flow of Charged Particles
}

\author{
Ousmane Sow ${ }^{1}$, Mamadou Lamine Ba ${ }^{2}$, Mohamed Abderrahim Ould El Moujtaba', \\ Youssou Traore ${ }^{3}$, El Hadji Sow ${ }^{2}$, Cheikh Tidiane Sarr², Masse Samba Diop², Grégoire Sissoko² \\ ${ }^{1}$ University Institute of Technology, University of Thiès, Thiès, Sénégal \\ ${ }^{2}$ Laboratory of Semiconductors and Solar Energy, Physics Department, Faculty of Science and Technology, University Cheikh \\ Anta Diop, Dakar, Senegal \\ ${ }^{3}$ Ecole Polytechnique de Thiès, Thiès, Sénégal \\ Email: gsissoko@yahoo.com
}

How to cite this paper: Sow, O., Ba, M.L., El Moujtaba, M.A.O., Traore, Y., Sow, El.H., Sarr, C.T., Diop, M.S. and Sissoko, G. (2020) Electrical Parameters Determination from Base Thickness Optimization in a Silicon Solar Cell under Influence of the Irradiation Energy Flow of Charged Particles. Energy and Power Engineering, 12, $1-15$. https://doi.org/10.4236/epe.2020.121001

Received: October 29, 2019

Accepted: December 28, 2019

Published: December 31, 2019

Copyright $\odot 2020$ by author(s) and Scientific Research Publishing Inc. This work is licensed under the Creative Commons Attribution International License (CC BY 4.0).

http://creativecommons.org/licenses/by/4.0/ (c) (i) Open Access

\begin{abstract}
In this work, we study the characteristics I-V and P-V of a silicon solar cell as well as its fill factor, its electrical power from the optimum thickness obtained in the base under variation of the irradiation energy flow of charged particles. The recombination velocity at the junction corresponding to the maximum power point was also deduced.
\end{abstract}

\section{Keywords}

Silicon Solar Cell, Flow Irradiation Energy, Recombination Velocity, Optimum Base Thickness

\section{Introduction}

Authors have studied the electrical parameters of the solar cell namely the fill factor, the conversion efficiency, the power, the I-V and P-V characteristics under the Influence of Irradiation [1], from the back surface recombination velocity modeling in white biased [2], under temperature with the junction surface recombination concept [3], by acquisition automatic of I-V properties and temperature [4] [5], under influence of incidence angle on a vertical Silicon Solar [6], by illumination wavelength effect on a parallel vertical junction silicon solar cell and under irradiation [7] and illumination level effects on macroscopic parameters of a bifacial solar cell [8]. 
Our study is to determinate these electrical parameters from the optimal base thickness of the solar cell under variation of the irradiation energy flow and extracting the values of the recombination velocity at the junction, corresponding to the maximum power.

\section{Presentation of the Solar Cell}

Figure 1 represents a $\mathrm{n}^{+}-\mathrm{p}-\mathrm{p}^{+}$silicon solar cell [9] [10]. The emitter is the thin $\left(\mathrm{n}^{+}\right)$zone covered by the front grids. Then comes the space charge region (SCR), which is formed by migration of the majority charges coming from the two semiconductors ( $\mathrm{n}^{+}$and $\mathrm{p}$ ), according to the principle of Helmotz or compensation law. They are formed as fixed charges that delimit a space, where there is an intense electric field, which will allow the dissociation of photogenerated electron-hole pairs, and their acceleration to the deficit areas in corresponding charge. The (p) zone is doped with boron atoms and represents the larger thickness base $(170-300 \mu \mathrm{m})$. It is the zone of pair creation (electron-hole), the most important, which justifies, the interest of its study in a solar cell. The $\left(\mathrm{p}^{+}\right)$zone over doped in boron atoms, allows the creation of another rear space charge region, where the created electric field (Back surface Field) will allow the minority carriers of the (p) zone to be pushed back to the junction, to be then collected and participated in the photocurrent.

\section{Theory}

The solar cell thus achieved (Figure 1) is previously subjected to a flow of charged particles $(\phi p)$ and intensity $(k)$ [11], allowing to simulate the conditions of operation outside the atmosphere, in the supply of satellites. Under polychromatic illumination, the density of charge carriers $\delta(x, \phi p, k l)$ generated at point of abscissa $x$ in the base, according to the law is defined by equation (Equation (1)), describing the generation rate [12] [13] and expressed as:

$$
G(x)=n \times \sum_{i=1}^{3} a_{i} \times e^{-b_{i} \cdot x}
$$

$\delta(x, \phi p, k l)$ follows the charge transport equation given by (Equation (2)):

$$
D\left(k l, \phi_{p}\right) \frac{\partial^{2} \delta\left(x, k l, \phi_{p}\right)}{\partial x^{2}}-\frac{\delta\left(x, k l, \phi_{p}\right)}{\tau}+G(x)=0
$$

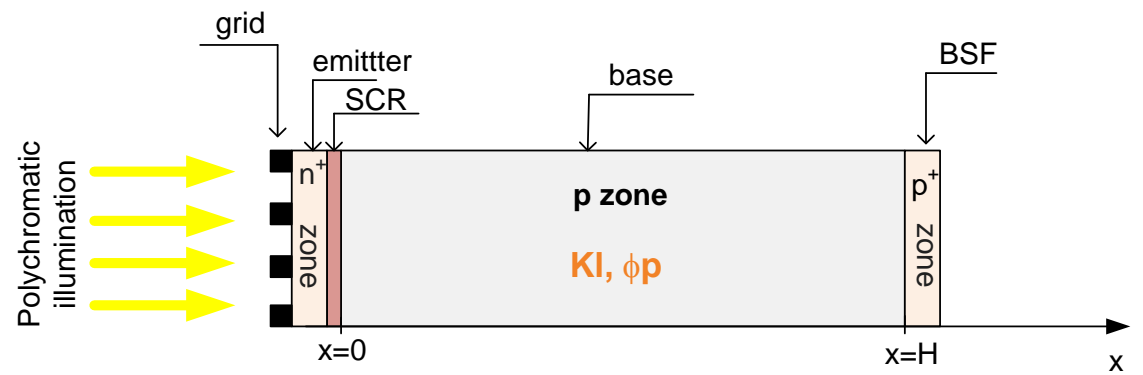

Figure 1. Structure of the monofacial silicon solar cell $\left(\mathrm{n}^{+}-\mathrm{p}-\mathrm{p}^{+}\right)$under irradiation. 
It is accompanied by the Equation (3) and Equation (4) specifying the conditions at the $(p)$ base boundaries in the 1D model, which define, the $S f$ [14] [15] [16] and $S b$ [17] [18] [19] recombination velocity rates, respectively at the junction $\left(\mathrm{n}^{+} / \mathrm{p}\right)$ at $x=0$, and in the rear $(\mathrm{p} / \mathrm{p})$, at $x=H$.

$$
\begin{gathered}
\left.D(k l, \phi p) \frac{\partial \delta(x, k l, \phi p)}{\partial x}\right|_{x=0}=S_{f} \times \delta(0, k l, \phi p) \\
\left.D(k l, \phi p) \frac{\partial \delta(x, k l, \phi p)}{\partial x}\right|_{x=H}=-S_{b} \times \delta(H, k l, \phi p)
\end{gathered}
$$

The diffusion term influenced by the irradiation conditions of the solar cell, is given by the following empirical relationship [11]:

$$
L\left(k l, \phi_{p}\right)=\frac{1}{\left(\frac{1}{L_{0}^{2}}+k l \times \phi_{p}\right)^{1 / 2}}
$$

where:

$L_{0}$ is the diffusion length of the excess minority carriers in absence of irradiation energy flux $\left(\phi_{p}\right) . L\left(k l, \phi_{p}\right)$ is the diffusion length of the excess minority carrier in the base as a function of the irradiation energy flux $(\phi p)$ and the damage coefficient intensity $(k l)$ and which may be related to Einstein's relationship by:

$$
\left[L\left(k l, \phi_{p}\right)\right]^{2}=\tau \times D\left(k l, \phi_{p}\right)
$$

$D\left(k l, \phi_{p}\right)$ and $\tau$ are respectively the diffusion coefficient and lifetime of the electrons in the base of the solar cell under irradiation.

The continuity Equation (2) solution is provided by:

$$
\delta(x, k l, \phi p)=A \times \cosh \left[\frac{x}{L(k l, \phi p)}\right]+B \times \sinh \left[\frac{x}{L(k l, \phi p)}\right]+\sum K_{i} \times e^{-b_{i} \cdot x}
$$

where, coefficients $A$ and $B$, will be obtained by use of Equation (3) and Equation (4).

\section{Results and Discussion}

\subsection{Expressions of Photocurrent, Recombination Velocity ( $\mathrm{Sb}$ ) and Phototension}

1) Fick's charged particle law establishes the photocurrent density of minority carriers, derived from the base by the following relationship:

$$
\begin{aligned}
J p h\left(S f, H, k l, \phi_{p}\right) & =q \cdot D\left(k l, \phi_{p}\right) \cdot\left[\frac{\partial \delta\left(S f, x, H, k l, \phi_{p}\right)}{\partial x}\right]_{x=0} \\
& =q \cdot D\left(k l, \phi_{p}\right) \frac{B\left(S f, H, k l, \phi_{p}\right)}{L\left(k l, \phi_{p}\right)}+\sum_{i=1}^{3} K_{i} \cdot b_{i}
\end{aligned}
$$

2) At the high values of recombination velocity at the junction, it is established that [16] [19] [20] [21]: 


$$
\left[\frac{\partial \operatorname{Jph}\left(S f, k l, \phi_{p}\right)}{\partial S f}\right]_{S f \succ 5 \times 10^{5} \mathrm{~cm} \cdot \mathrm{s}^{-1}}=0
$$

Derived from this equation, it gives the following relations:

$$
\text { i) } S b 0(H, k l, \phi p) \frac{L(k l, \phi p)}{D(k l, \phi p)}=-\tanh \left(\frac{H}{L(k l, \phi p)}\right)
$$

Equation (10), gives rise the definition of intrinsic velocity and becomes a diffusion velocity [19], when $H$ is very large compared to $L$.

$$
\text { ii) } \begin{aligned}
\quad \operatorname{sbl}(H, k l, \phi p) \frac{L(k l, \phi p)}{D(k l, \phi p)} \\
\quad=\sum_{i=1}^{3} \frac{L(k l, \phi p) \times b_{i} \times\left(e^{b_{i} \cdot H}-\cosh \left(\frac{H}{L(k l, \phi p)}\right)\right)-\sinh \left(\frac{H}{L(k l, \phi p)}\right)}{-L(k l, \phi p) \times b_{i} \times \sinh \left(\frac{H}{L(k l, \phi p)}\right)+\cosh \left(\frac{H}{L(k l, \phi p)}\right)-e^{b_{i} \cdot H}}
\end{aligned}
$$

Equation (11) is marked by a term of absorption $\left(b_{i}\right)$ and leads to generation velocity, when $H$ is small compared to $L$ [19].

3) By Boltzmann's law, the photovoltage at the junction is written as:

$$
\operatorname{Vph}\left(S f, H, k l, \phi_{p}\right)=\frac{K b \times T}{q} \cdot \ln \left(\frac{N b}{n_{i}^{2}} \cdot \delta\left(0, H, k l, \phi_{p}\right)+1\right)
$$

where, $K b$ is the Boltzmann constant, $q$ is the elementary charge of the electron and $T$ is the temperature. $N b$ is the solar cell base doping rate, and $n_{i}$ is the intrinsic density of minority charge carriers.

\subsection{Optimum Thickness of the Base, Deduced from Each Case of Irradiation Flow}

The expressions (Equation (10) and Equation (11)) are represented by the Figure 2, allowing to obtain the optimum thickness (abscissa of intercept point) of the base [22] [23] for different cases of irradiation of the solar cell, and presented by Table 1 . These results are decisive for the characterization of the solar cell under irradiation, through the calculation of photocurrent density, photovoltage and conversion efficiency.

\section{3. $J p h(S f, \phi p, H o p t)-V(S f, \phi p$, Hopt $)$ Characteristic}

The profile of the $J p h(S f, \phi p, H o p t)-V(S f, \phi p, H o p t)$ characteristic for different values of the irradiation energy flow and base optimum thickness is shown in Figure 3. We note that the photocurrent density $(J(S f, \phi p, H o p t))$ decreases

Table 1. Base optimum thickness values obtained for different irradiation energy flow.

\begin{tabular}{cccccc}
\hline$\phi p(\mathrm{MeV})$ & $\mathbf{6 0}$ & $\mathbf{8 0}$ & $\mathbf{1 0 0}$ & $\mathbf{1 2 0}$ & $\mathbf{1 4 0}$ \\
\hline $\operatorname{Hopt}(\mu \mathrm{m})$ & 127 & 123 & 120 & 117 & 114 \\
\hline
\end{tabular}




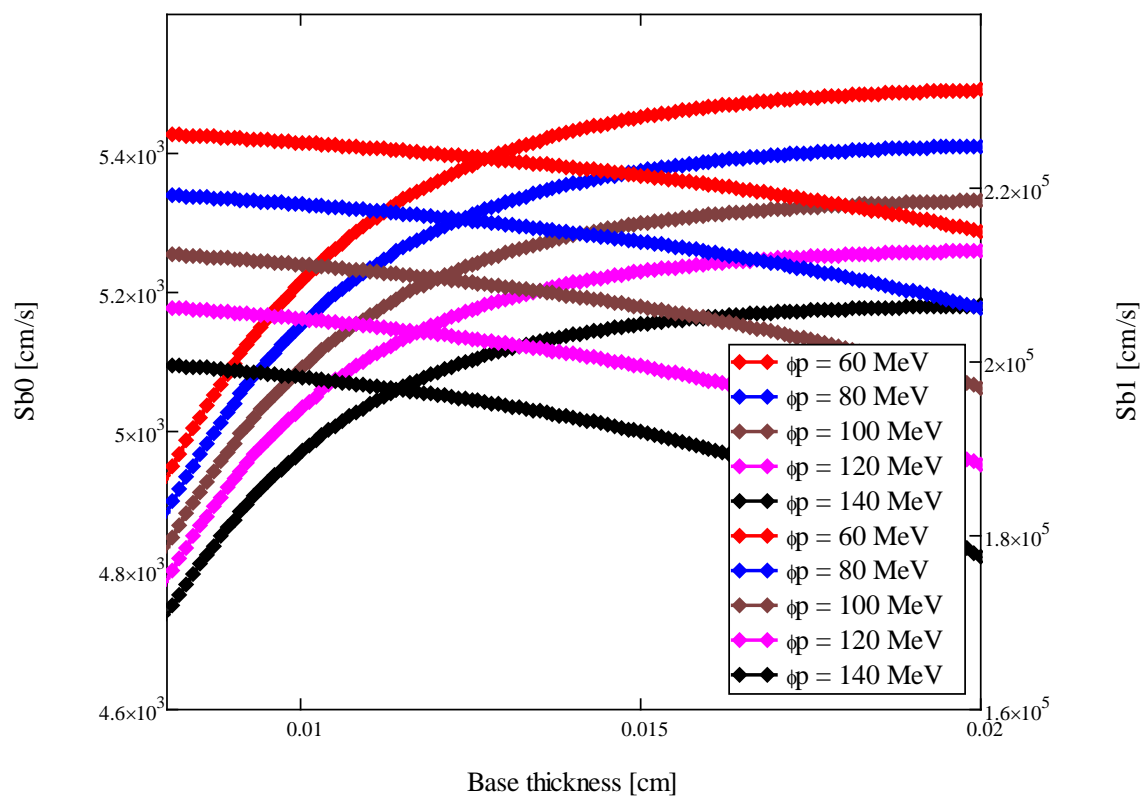

Figure 2. Recombination velocity versus solar cell base thickness with $k l=5 \mathrm{~cm}^{-2} / \mathrm{MeV}, \tau$ $=10^{-6} \mathrm{~s}$.

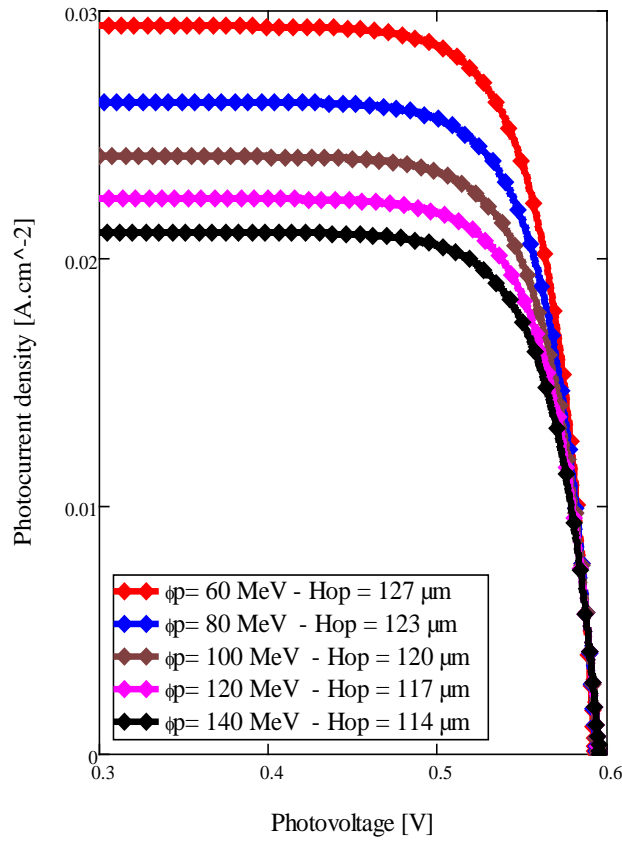

Figure 3. Characteristic photocurrent density versus photovoltage for different irradiation energy flow and base thickness with $k l=5 \mathrm{~cm}^{-2} / \mathrm{MeV}$.

with the increase of the irradiation energy flow. And the photovoltage increases slightly.

\subsection{Electrical Power of the Solar Cell}

Figure 4 represents the equivalent electric circuit of an illuminated solar cell [9]. 


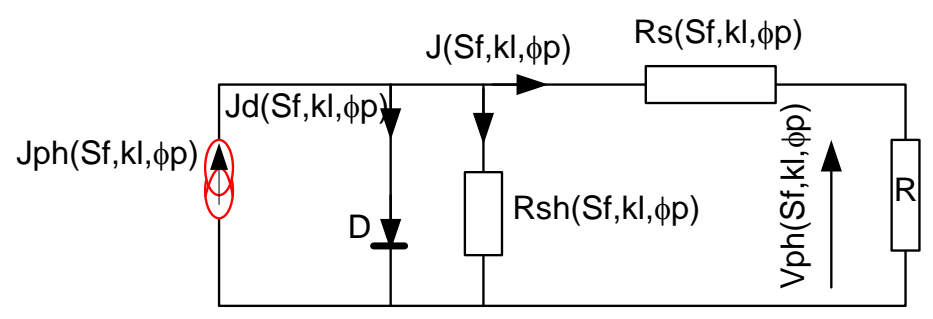

Figure 4. Equivalent electrical circuit of an illuminated solar cell.

The Ohm law applied to the circuit in Figure 4 yields the electric power delivered by the base of the solar cell to an external load as follows:

$$
P(S f, k l, \phi p)=\operatorname{Vph}(S f, k l, \phi p) \times J(S f, k l, \phi p)
$$

with:

$$
J(S f, k l, \phi p)=J p h(S f, k l, \phi p)-J_{d}(S f, k l, \phi p)
$$

where $J_{d}$ is the solar cell density of current under dark expressed as:

$$
J_{d}(S f, k l, \phi p)=q \times S f_{0} \times \frac{n_{i}^{2}}{N b} \times \exp \left(\frac{\operatorname{Vph}\left(S f, k l, \phi_{p}\right)}{V_{T}}-1\right)
$$

$S f_{0}$ is the excess minority carrier recombination velocity associated with shunt resistance-induced charge carrier losses [24] [25], which characterizes the quality of the solar cell [15] [16] [20]. The expression intrinsic recombination velocity at the junction is given in static regime [26] [27] and under polychromatic illumination, by [28] and applied her for solar cell under irradiation as:

$$
S f_{0}(k l, \phi p)=\sum_{i=1}^{3} K_{i} \times \frac{D(k l, \phi p) \times\left[b_{i} \times L(k l, \phi p)-e^{-b_{i} \times H} \times\left(\operatorname{sh}\left(\frac{H}{L(k l, \phi p)}\right)+b_{i} \times L(k l, \phi p) \times c h\left(\frac{H}{L(k l, \phi p)}\right)\right)\right]}{L(k l, \phi p) \times\left[e^{-b_{i} \times H} \times\left(\operatorname{ch}\left(\frac{H}{L(k l, \phi p)}\right)+b_{i} \times L(k l, \phi p) \times \operatorname{sh}\left(\frac{H}{L(k l, \phi p)}\right)\right)-1\right]}(16)
$$

\section{5. $P(S f, \phi p$, Hopt $)-V(S f, \phi p$, Hopt $)$ Characteristic}

Figure 5 and Figure 6 show the variations in electrical power as function of both, the excess minority carrier recombination velocity at the junction and the photovoltage for different irradiation energy flow and optimum base thickness.

We note on Figure 5, the decrease of maximum power amplitude with the irradiation energy flow corresponding the base thickness.

On Figure 6, it is also observed a decrease in power with the increase of irradiation energy flow corresponding the optimum base thickness.

\subsection{Fill Factor and Efficiency}

\subsubsection{Fill Factor}

The fill factor is an important parameter for a solar cell. It shows the physical quality of the solar cell for a conversion efficiency and indicates the performance of a perfect cell. The expression of the fill factor is given [29] as: 


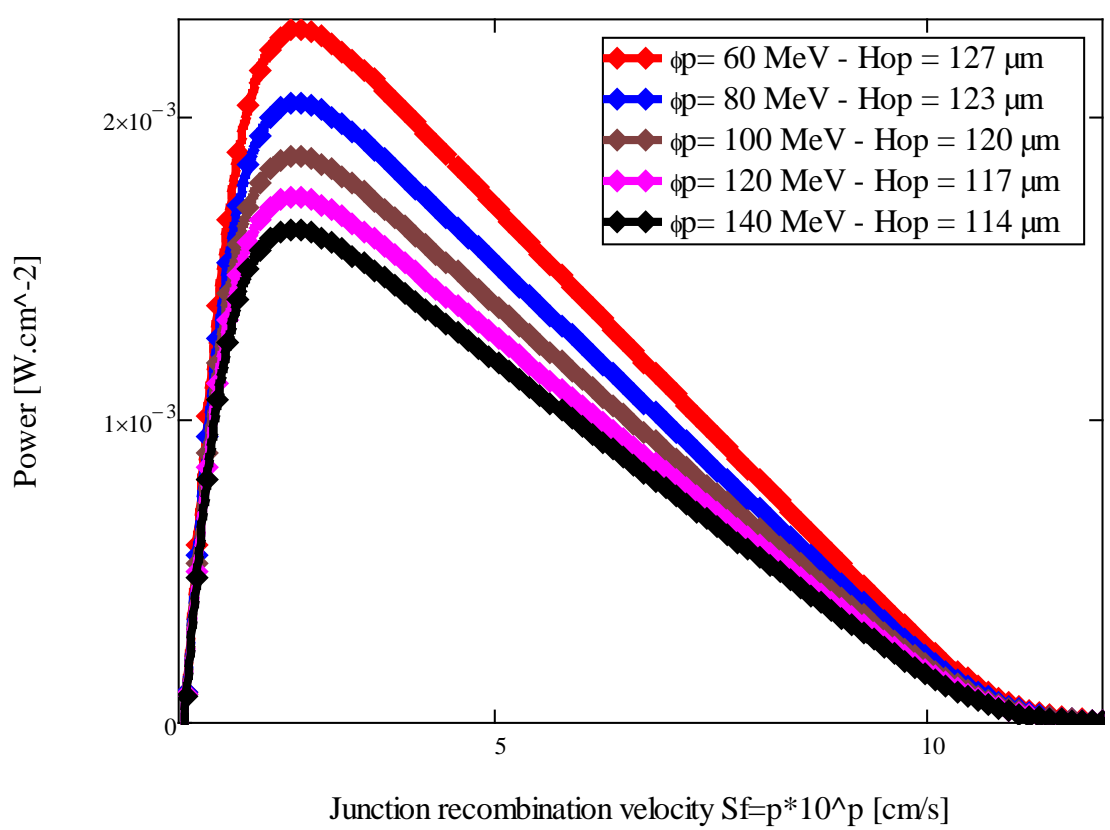

Figure 5. Solar cell power versus junction recombination velocity for different irradiation energy flow and base thickness with $k l=5 \mathrm{~cm}^{-2} / \mathrm{MeV}$.

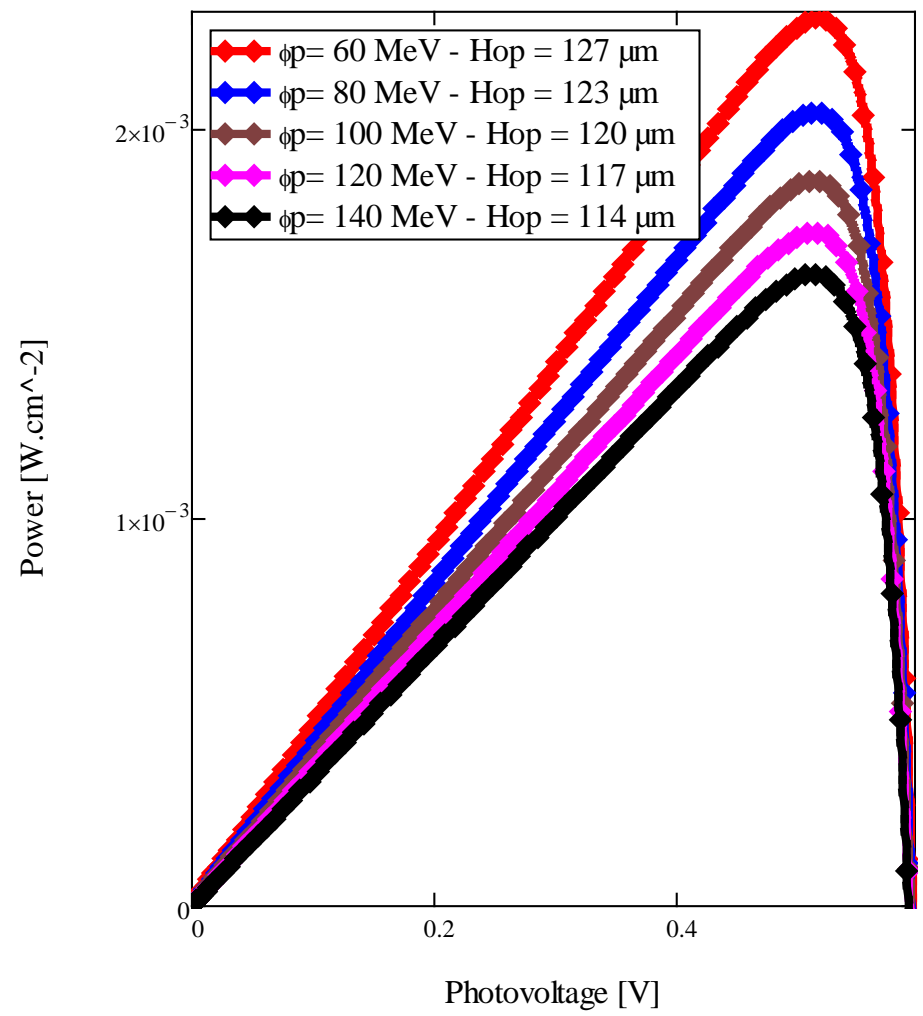

Figure 6. Solar cell power versus photovoltage for different irradiation energy flow and base thickness with $\mathrm{kl}=5 \mathrm{~cm}^{-2} / \mathrm{MeV}$.

$$
F F=\frac{P_{\max }}{V_{O C} \times J_{S C}}
$$


$P_{\max }$ is the maximum power. Voc is the open circuit photovoltage.

$J_{s c}$ is the short circuit current density

\subsubsection{Efficiency}

The conversion efficiency of a solar cell is the ratio between the maximum power supplied provided by the solar cell and the power of absorbed illumination. It is written as follows:

$$
\eta=\frac{J_{S C \max } \times V_{\max }}{P_{\text {incident }}}
$$

$P_{\text {incident }}$ is the incident light power absorbed by the solar cell.

With: $P_{\text {incident }}=100 \mathrm{~mW} \cdot \mathrm{cm}^{-2}$ in the standard conditions (Air Mass 1.5).

The obtained solar cell fill factor and efficiency for different irradiation energy flow values corresponding to the optimum thickness are shown in $\mathrm{Ta}$ ble 2 .

\subsubsection{Curves of Power and Efficiency}

Figure 7 represents the profil of the power versus irradiation energy, Figure 8 and Figure 9 represent the profils of the power and the efficiency versus the optimum base thickness.

Table 2. Table of parameters leading to the fill factor and efficiency corresponding to the optimum base thickness for different irradiation energy flow.

\begin{tabular}{cccccc}
\hline$\phi p(\mathrm{MeV})$ & $\mathbf{6 0}$ & $\mathbf{8 0}$ & $\mathbf{1 0 0}$ & 120 & 140 \\
\hline$H o p t(\mathrm{~cm})$ & 0.0127 & 0.0123 & 0.0120 & 0.0117 & 0.0114 \\
$J_{s m \max }\left(\mathrm{A} / \mathrm{cm}^{2}\right)$ & 0.0295 & 0.0263 & 0.0242 & 0.0224 & 0.0212 \\
$J_{d}\left(S f_{\max }\right)\left(\mathrm{A} / \mathrm{cm}^{2}\right)$ & $0.1374 \times 10^{-3}$ & $0.1355 \times 10^{-3}$ & $0.1342 \times 10^{-3}$ & $0.1330 \times 10^{-3}$ & $0.1318 \times 10^{-3}$ \\
$V_{\max }(\mathrm{V})$ & 0.5931 & 0.5940 & 0.5946 & 0.5951 & 0.5955 \\
$P_{\max }\left(\mathrm{W} / \mathrm{cm}^{2}\right)$ & 0.01741 & 0.01554 & 0.01431 & 0.01325 & 0.01254 \\
$F F$ & 0.9951 & 0.9947 & 0.9945 & 0.9939 & 0.9933 \\
$\eta_{\max }(\%)$ & 17.41 & 15.54 & 14.31 & 13.25 & 12.55 \\
\hline
\end{tabular}

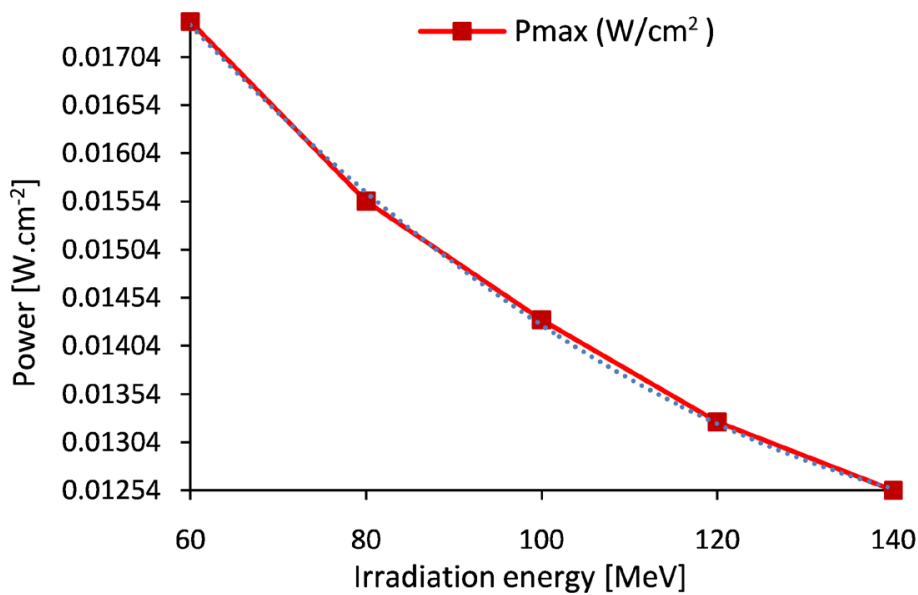

Figure 7. Power versus irradiation energy. 


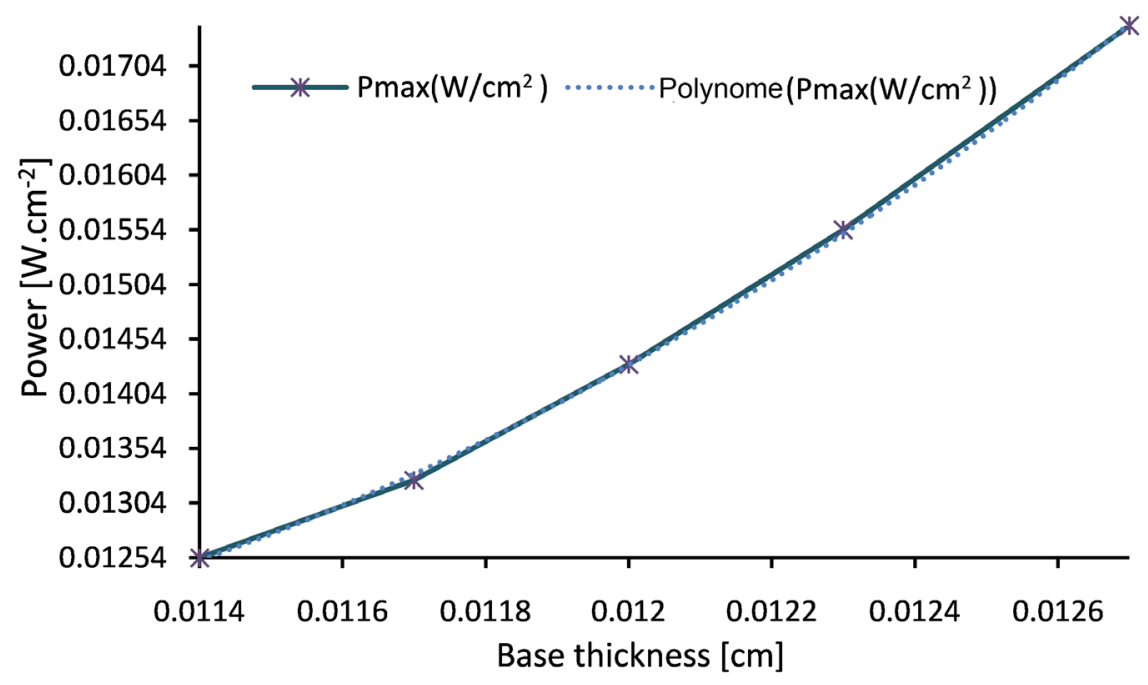

Figure 8. Power versus base thickness.

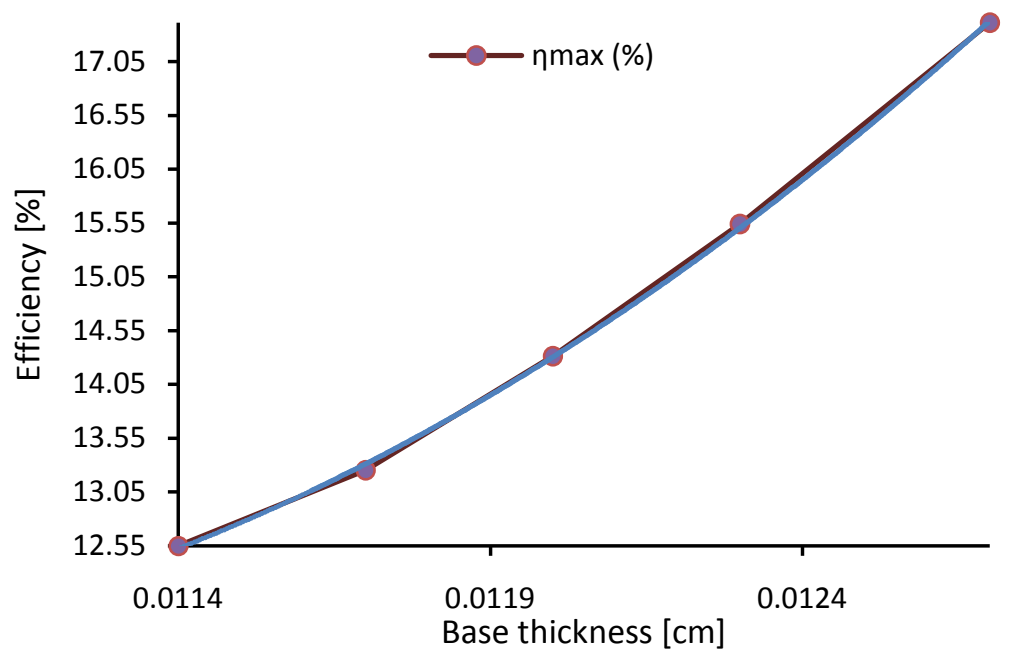

Figure 9. Efficiency versus optimum base thickness.

The equation obtained from the power versus the irradiation energy is given by the following relation:

$$
P_{\max }=u \times \phi p^{2}-w \times \phi p+z
$$

with: $u=4 \times 10^{-7} \mathrm{~W} \cdot \mathrm{cm}^{-2} / \mathrm{MeV}, \quad w=10^{-4} \mathrm{~W} \cdot \mathrm{cm}^{-2} / \mathrm{MeV}, \quad z=0.0247 \mathrm{~W} / \mathrm{cm}^{2}$

The equation obtained from the power versus the base thickness is given by the following relation:

$$
P_{\max }=\alpha \times H^{2}-\beta \times H+v
$$

with: $\alpha=1140.6 \mathrm{~W} / \mathrm{cm}^{4}, \beta=23.709 \mathrm{~W} / \mathrm{cm}^{3}, \quad v=0.1346 \mathrm{~W} / \mathrm{cm}^{2}$

The fit equation obtained from the efficiency versus the base thickness is given by the following relation:

$$
\eta_{\max }=m \times H^{2}-n \times H+k
$$

with: $m=10^{6} \mathrm{~cm}^{-2}, \quad n=24038 \mathrm{~cm}^{-1}, k=136.58$ 
We note on Figure 8 and Figure 9 that the power and the efficiency increase with the increasing base thickness.

\subsection{Recombination Velocity Sfmax at the Junction}

$S f_{\max }$, the excess minority carrier recombination velocity at the junction corresponding to the maximum power point is point out by solving the following equation [3] [30].

$$
\frac{\partial P}{\partial S f}=0
$$

From this Equation (22), the transcendental equation depending on recombination velocity $S f$ and the irradiation energy is obtained, for each Hopt. It is given by the following expressions:

$$
\begin{aligned}
& M\left(S F_{\text {max }}, k l, \phi p\right) \\
& =\frac{1}{S F_{\text {max }} \times L(k l, \phi p)} \times\left[1-\frac{S F_{\text {max }} \times L(k l, \phi p)}{Y 1 \times D(k l, \phi p)+S F_{\text {max }} \times L(k l, \phi p)}\right] \\
N & {\left[S F_{\text {max }}, k l, \phi p\right) } \\
= & {\left[\frac{\Gamma_{\text {max }}(0, k l, \phi p)}{\left(\Gamma_{\text {max }}(0, k l, \phi p)+\frac{n i^{2}}{N b}\right) \times\left(S F_{\text {max }} \times L(k l, \phi p)+Y 1 \times D(k l, \phi p)\right)}\right] } \\
& \times\left[\frac{1}{\log \left(\frac{N b \times \Gamma_{\text {max }}(0, k l, \phi p)}{n i^{2}}+1\right)}\right]
\end{aligned}
$$

$\Gamma_{\max }(0, k l, \phi p)$ is the density of the minority excess minority carrier at the point of maximum power, its expression is given by the following relations:

$$
\Gamma_{\max }(0, k l, \phi p)=\beta \times D(k l, \phi p) \times\left[\frac{Y 2+Y 1-b_{i} \times L(k l, \phi p)}{S F_{\max } \times L(k l, \phi p)+Y 1 \times D(k l, \phi p)}\right]
$$

with:

$$
\begin{gathered}
\beta=-\frac{a_{i} \times L(k l, \phi p)^{2} \times n}{D(k l, \phi p) \times\left(L(k l, \phi p)^{2} \times b_{i}^{2}-1\right)} \\
Y 1=\frac{\frac{D(k l, \phi p)}{L(k l, \phi p)} \times \sinh \left(\frac{H}{L(k l, \phi p)}\right)+S b(k l, \phi p) \times \cosh \left(\frac{H}{L(k l, \phi p)}\right)}{\frac{D(k l, \phi p)}{L(k l, \phi p)} \times \cosh \left(\frac{H}{L(k l, \phi p)}\right)+S b(k l, \phi p) \times \sinh \left(\frac{H}{L(k l, \phi p)}\right)} \\
Y 2=\frac{\left(D(k l, \phi p) \times b_{i}-S b(k l, \phi p)\right) \times \exp \left(-b_{i} \cdot H\right)}{\frac{D(k l, \phi p)}{L(k l, \phi p)} \times \cosh \left(\frac{H}{L(k l, \phi p)}\right)+S b(k l, \phi p) \times \sinh \left(\frac{H}{L(k l, \phi p)}\right)}
\end{gathered}
$$


The graphical resolution of this transcendental equation as a function of the excess minority carrier recombination velocity $S f$ at the junction [30], for different irradiation energy flow corresponding the optimum base thickness, gives the $S f_{\max }$ values by the intercept point of the two curves represented by Figure 10.

The results obtained from Figure 10 corresponding to the numerical values of $S f_{\max }$, are given in Table 3.

The recombination velocity $S f_{\max }$ of the excess minority carrier at the junction yielding $P_{\max }$, decreases while irradiation energy flow increases.

Curve $S f_{\max }\left(H_{o p t}\right)$

Figure 11 represents the profil of the recombination velocity $S f_{\max }$ of the excess minority carrier at the junction yielding $P_{\max }$, as function of optimum base thickness.

Table 3. The numerical values of $S f_{\max }$ for different irradiation energy flow and the optimum base thickness.

\begin{tabular}{cccc}
\hline $\begin{array}{c}\text { Irradiation energy } \\
(\mathrm{MeV})\end{array}$ & $\begin{array}{c}\text { Base thickness } \\
(\mathrm{cm})\end{array}$ & $\begin{array}{c}\text { Intercept points curves } \\
(p)\end{array}$ & $\begin{array}{c}\text { Sfmax } \\
\left(p \cdot 10^{p} \mathrm{~cm} / \mathrm{s}\right)\end{array}$ \\
\hline $\mathbf{6 0}$ & 0.0127 & 1.9683 & 182.975 \\
$\mathbf{8 0}$ & 0.0123 & 1.9638 & 180.675 \\
100 & 0.0120 & 1.9600 & 178.754 \\
120 & 0.0117 & 1.9564 & 176.953 \\
140 & 0.0114 & 1.9534 & 175.465 \\
\hline
\end{tabular}

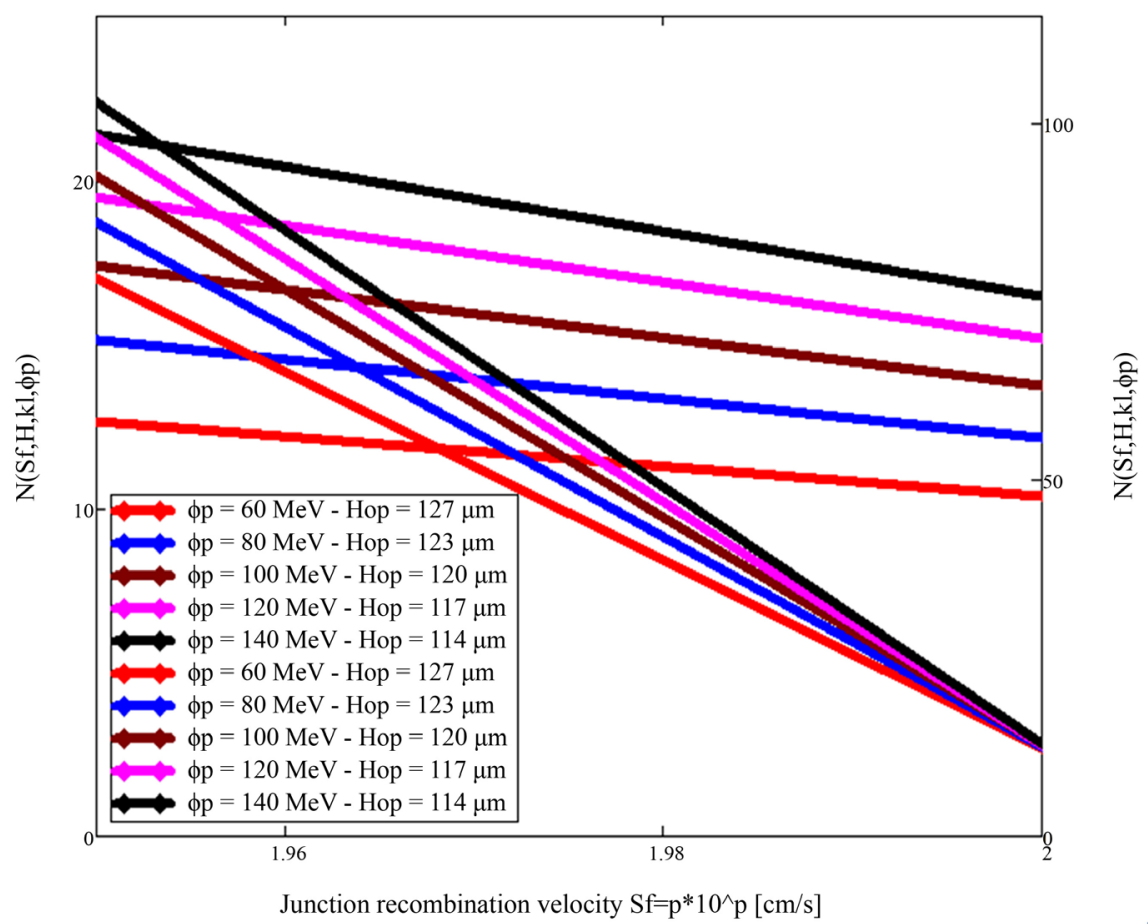

Figure 10. Representation of transcendental equation versus. 


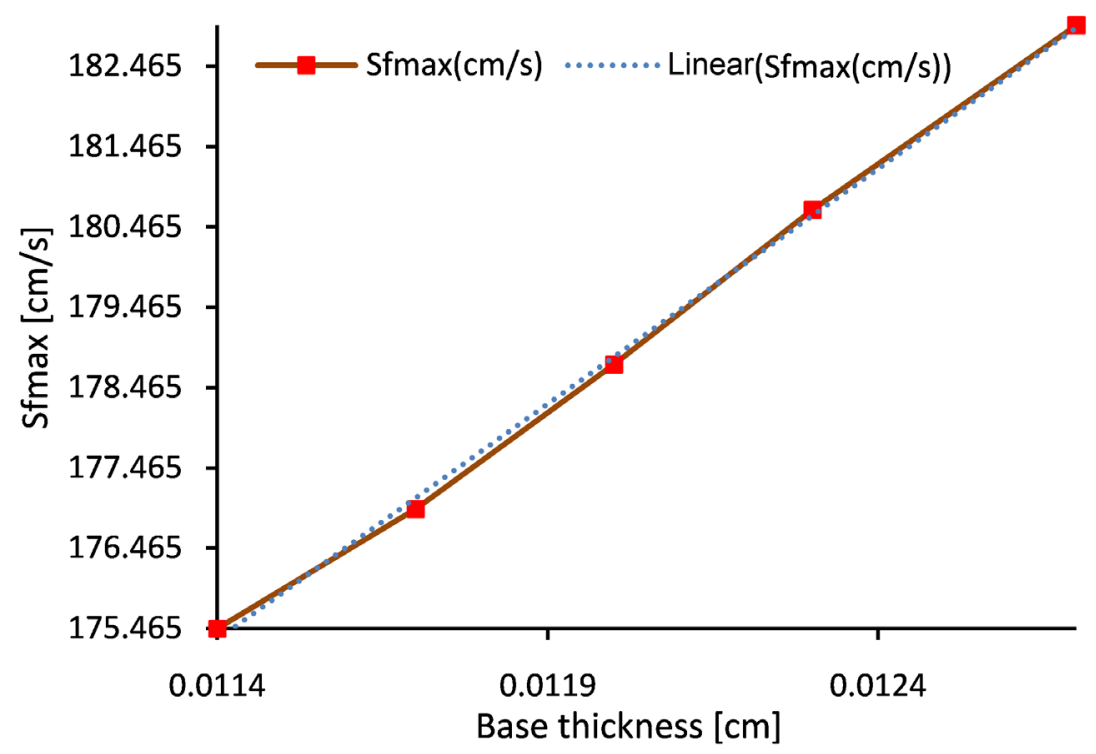

Figure 11. $S f_{\max }$ versus optimum base thickness.

The equation obtained from the best fit of $S f_{\max }$ versus base optimum thickness is given by the following relation:

$$
S f_{\max }=a \times H_{\text {Opt }}+b
$$

with: $a=5859.6 \mathrm{~s}^{-1}, \quad b=108.53 \mathrm{~cm} \cdot \mathrm{s}^{-1}$

The recombination velocity $S f_{\max }$ of the excess minority carrier at the junction increases with the optimum base thickness.

\section{Conclusion}

In this work, a technique for obtaining the optimum thickness of the solar cell under variation of the irradiation energy flow has been presented. It is also deduced from this optimal thickness, the fill factor, the electrical power, the efficiency of the solar cell as well as the recombination velocity at the junction through a transcendental equation, leading to maximum power. We found that the electrical parameters of the solar cell decrease with the increasing of the irradiation energy flow. Then we have plotted and fitted the curves of the power, the efficiency and the recombination velocity (at the maximum power) versus the optimum base thickness.

\section{Conflicts of Interest}

The authors declare no conflicts of interest regarding the publication of this paper.

\section{References}

[1] Ould El Moujtaba, M.A., Ndiaye, M., Diao, A., Thiame, M., Barro, I.F. and Sissoko, G. (2012) Theoretical Study of the Influence of Irradiation on a Silicon Solar Cell under Multispectral Illumination. Research Journal of Applied Sciences, Engineering and Technology, 4, 5068-5073. 
[2] Diasse, O., Diao, A., Wade, M., Diouf, M.S., Diatta, I., Mane, R., Traore, Y. and Sissoko, G. (2018) Back Surface Recombination Velocity Modeling in White Biased Silicon Solar Cell under Steady State. Journal of Modern Physics, 9, 189-201. https://doi.org/10.4236/jmp.2018.92012

[3] Diatta, I., Ly, I., Wade, M., Diouf, M.S., Mbodji, S. and Sissoko, G. (2016) Temperature Effect on Capacitance of a Silicon Solar Cell under Constant White Biased Light. World Journal of Condensed Matter Physics, 6, 261-268. https://doi.org/10.4236/wjcmp.2016.63024

[4] Sow, O., Diarisso, D., MBodji, N.Z.A., Diallo, M.S., Diao, A., Gaye, I., Barro, F.I. and Sissoko, G. (2013) Experimental Device for Acquisition of Properties I-V and V (T) of the Solar by Automatic Change Operating Point. International Journal of Innovative Technology and Exploring Engineering, 2, 330-334.

[5] Dione, B., Sow, O., Wade, M., Ibrahima, L.Y., Mbodji, S. and Sissoko, G. (2016) Experimental Processus for Acquisition Automatic Features of I-V Properties and Temperature of the Solar Panel by Changing the Operating Point. Circuits and Systems, 7, 3984-4000. http://www.scirp.org/journal/cs https://doi.org/10.4236/cs.2016.711330

[6] Sahin, G., Diouf, M.S., Thiam, A., Ngom, M.I., Diasse, O. and Sissoko, G. (2017) Influence of Incidence Angle on the Electrical Parameters of a Vertical Silicon Solar Cell. Current Trends in Technology and Science, 4, 673-679. http://www.ctts.in

[7] Dieng, A.B., Seibou, B., Ndiaye, S.A., Wade, M., Diouf, M.S., Ibrahima, L.Y. and Sissoko, G. (2016) Illumination Wavelength Effect on Electrical Parameters of a Parallel Vertical Junction Silicon Solar Cell under Steady State and under Irradiation. International Journal of Research in Engineering and Technology, 5, 1-8. https://ijret.org/ https://doi.org/10.15623/ijret.2017.0612009

[8] Nzonzolo, Lilonga-Boyenga, D. and Sissoko, G. (2014) Illumination Level Effects on Macroscopic Parameters of a Bifacial Solar Cell. Energy and Power Engineering, 6, 25-36. http://www.scirp.org/journal/epe https://doi.org/10.4236/epe.2014.63004

[9] Fossum, G., Burgess, E.L. and Lindholm, F.A. (1978) Silicon Solar Cell Designs Based on Physical Behavior in Concentrated Sunlight. Solid-State Electronics, 27, 729-737. https://doi.org/10.1016/0038-1101(78)90005-9

[10] Le Quang, N., Rodot, M., Nijs, J., Ghannam, M. and Coppye, J. (1992) Réponse spectrale de photopiles de haut rendement au silicium multicristallin. Journal de Physique III France, 2, 1305-1316. https://doi.org/10.1051/jp3:1992108

[11] Gaye, I., Sam, R., Seré, A.D., Barro, I.F., Ould El Moujtaba, M.A., Mané, R. and Sissoko, G. (2012) Effect of Irradiation on the Transient Response of a Silicon Solar Cell. International Journal of Emerging Trends and Technologies in Computer Science, 1, 210-214.

[12] Furlan, J. and Amon, S. (1985) Approximation of the Carrier Generation Rate in Illuminated Silicon. Solid State Electronics, 28, 1241-1243. https://doi.org/10.1016/0038-1101(85)90048-6

[13] Mohammad, S.N. (1987) An Alternative Method for the Performance Analysis of Silicon Solar Cells. Journal of Applied Physics, 28, 767-772. https://doi.org/10.1063/1.338230

[14] Zondervan, A., Verhoef, L.A. and Lindholm, F.A. (1988) Measurement Circuits for Silicon-Diode and Solar Cells Lifetime and Surface Recombination Velocity by Electrical Short-Circuit Current Decay. IEEE Transactions on Electron Devices, 35, 
85-88. https://doi.org/10.1109/16.2419

[15] Sissoko, G., Sivoththanam, S., Rodot, M. and Mialhe, P. (1992) Constant Illumination-Induced Open Circuit Voltage Decay (CIOCVD) Method, as Applied to High Efficiency Si Solar Cells for Bulk and Back Surface Characterization. 11 th European Photovoltaic Solar Energy Conference and Exhibition, Montreux, 352-354.

[16] Diallo, H.L., Seïdou Maiga, A., Wereme, A. and Sissoko, G. (2008) New Approach of Both Junction and Back Surface Recombination Velocities in a 3D Modelling Study of a Polycrystalline Silicon Solar Cell. The European Physical Journal Applied Physics, 42, 203-211. https://doi.org/10.1051/epjap:2008085

[17] Rose, B.H. and Weaver, H.T. (1983) Determination of Effective Surface Recombination Velocity and Minority-Carrier Lifetime in High-Efficiency Si Solar Cells. Journal of Applied Physics, 54, 238-247. https://doi.org/10.1063/1.331693

[18] Joardar, K., Dondero, R.C. and Schroda, D.K. (1989) Critical Analysis of the Small-Signal Voltage-Decay Technique for Minority-Carrier Lifetime Measurement in Solar Cells. Solid-State Electronics, 32, 479-483. https://doi.org/10.1016/0038-1101(89)90030-0

[19] Sissoko, G., Museruka, C., Corréa, A., Gaye, I. and Ndiaye, A.L. (1996) Light Spectral Effect on Recombination Parameters of Silicon Solar Cell. World Renewable Energy Congress, Pergamon, Part III, 1487-1490.

[20] Bocande, Y.L., Correa, A., Gaye, I., Sow, M.L. and Sissoko, G. (1994) Bulk and Surfaces Parameters Determination in High Efficiency Si Solar Cells. Proceedings of the World Renewable Energy Congress, Pergamon, Part III, Vol. 3, 1698-1700.

[21] Sissoko, G., Nanema, E., Correa, A., Biteye, P.M., Adj, M. and Ndiaye, A.L. (1998) Silicon Solar Cell Recombination Parameters Determination Using the Illuminated I-V Characteristic. Renewable Energy, 3, 1848-1851.

[22] Ba, M.L., Thiam, N., Thiame, M., Traore, Y., Diop, M.S., Ba, M., Sarr, C.T., Wade, M. and Sissoko, G. (2019) Base Thickness Optimization of a $\left(\mathrm{n}^{+}-\mathrm{p}-\mathrm{p}^{+}\right)$Silicon Solar Cell in Static Mode under Irradiation of Charged Particles. Journal of Electromagnetic Analysis and Applications, 11, 173-185. https://doi.org/10.4236/jemaa.2019.1110012

[23] Diop, M.S., Ba, H.Y., Thiam, N., Diatta, I., Traore, Y., Ba, M.L., Sow, E.H., Mballo, O. and Sissoko, G. (2019) Surface Recombination Concept as Applied to Determinate Silicon Solar Cell Base Optimum Thickness with Doping Level Effect. World Journal of Condensed Matter Physics, 9, 102-111.

https://www.scirp.org/journal/wjcmp https://doi.org/10.4236/wjcmp.2019.94008

[24] Thiam, N., Diao, A., Ndiaye, M., Dieng, A., Thiam, A., Sarr, M., Maiga, A.S. and Sissoko, G. (2012) Electric Equivalent Models of Intrinsic Recombination Velocities of a Bifacial Silicon Solar Cell under Frequency Modulation and Magnetic Field Effect. Research Journal of Applied Sciences, Engineering and Technology, 4, 4646-4655. https://doi.org/10.19026/rjaset.5.4825

[25] Ly Diallo, H., Wade, M., Ly, I., Ndiaye, M., Dieng, B., Lemrabott, O.H., Maïga, A.S. and Sissoko, G. (2002) 1D Modeling of a Bifacial Silicon Solar Cell under Frequency Modulation, Monochromatic Illumination: Determination of the Equivalent Electrical Circuit Related to the Surface Recombination Velocity. Research Journal of Applied Sciences, Engineering and Technology, 4, 1672-1676.

[26] Barro, F.I., Zerbo, I., Lemrabott, O.H., Zougomore, F. and Sissoko, G. (2001) Bulk and Surface Recombination Measurement in Silicon Double Sided Surface Field Solar Cell under Constant White Bias Illumination. Proceedings of 17 th European 
Photovoltaic Solar Energy Conference and Exhibition, Munich, 22-26 October 2001, 368-371.

[27] Dione, M.M., Ly, I., Diao, A., Gueye, S., Gueye, A., Thiame, M. and Sissoko, G. (2013) Determination of the Impact of the Grain Size and the Recombination Velocity at Grain Boundary on the Values of the Electrical Parameters of a Bifacial Polycristallin Silicon Solar Cell. IRACST_Engineering Science and Technology: An International Journal (ESTI), 3, 66-73.

[28] Ndiaye, E.H., Sahin, G., Dieng, M., Thiam, A.Y, Diallo, H.L., Ndiaye, M. and Sissoko, G. (2015) Study of the Intrinsic Recombination Velocity at the Junction of Silicon Solar under Frequency Modulation and Irradiation. Journal of Applied Mathematics and Physics, 3, 1522-1535. https://doi.org/10.4236/jamp.2015.311177 http://www.scirp.org/journal/jamp

[29] Sissoko, G., Correa, A., Nanema, E., Diarra, M.N., Ndiaye, A.L. and Adj, M. (1998) Recombination Parameters Measurement in Silicon Double Sided Surface Field Cell. Proceeding of the World Renewable Energy Congress, Florence, 20-25 September 1998, 1856-1859.

[30] Sylla, B.D.D., Ly, I., Sow, O., Dione, B., Traore, Y. and Sissoko, G. (2018) Junction Surface Recombination Concept as Applied to Silicon Solar Cell Maximum Power Point Determination Using Matlab/Simulink: Effect of Temperature. Journal of Modern Physics, 9, 172-188. https://doi.org/10.4236/jmp.2018.92011 